INOBIS: Jurnal Inovasi Bisnis dan Manajemen Indonesia

Volume 1, Nomor 1, Desember 2017

Utik Bidayati

\title{
Tinjuan Konseptual Aplikasi Balance Score Card Pada Perusahaan Umkm
}

\author{
Utik Bidayati \\ Universitas Ahmad Dahlan
}

\begin{abstract}
Abstrak
Keselarasan tujuan organisasi dan individu dalam organisasi sangat penting untuk dapat meningkatkan kinerja organisasi. Pengukuran kinerja dalam strategi organisasi dapat dilakukan dengan berbagai cara, diantaranya dengan menggunakan Balance Score Card. Balanced Scorecard merupakan salah satu ukuran kinerja alternatif yang bertujuan untuk menggabungkan ukuran kinerja keuangan dan non keuangan. Diinspirasi oleh Kaplan dan Norton, konsep ini dikembangkan dalam empat perspektif yaitu keuangan, pelanggan, proses internal serta pembelajaran dan pertumbuhan. Tulisan ini membahas bagaiman melakukan penilaian kinerja dengan menggunakan balanced scorecard.
\end{abstract}

Kata kunci: Penilaian kinerja; balanced scorecard; sistem manajemen strategis

\section{Pendahuluan}

Tata kelola organisasi yang baik (good corporate governance) merupakan sebuah kondisi yang harus diwujudkan organisasi untuk dapat mencapai kinerja yang maksimal. Perwujudan tata kelola organisasi yang baik dipengaruhi oleh kemampuan pemimpinnya dalam membawa dan mengajak semua sumberdaya yang dimilikinya pada tujuan organisasi yaitu visi dan misinya. Terdapat tantangan organisasi untuk mewujudkan kinerja yang lebih baik, yang diharapkan dari pihak internal maupun eksternal organisasi. Untuk dapat memenuhi tuntutan dan harapan tersebut, organisasi harus memiliki "keunggulan kompetitif", yaitu suatu keunggulan organisasi yang tidak mudah disaingi oleh kompetitor. Melalui strategi, organsasi mencapai keunggulan kompetitif ini, organisasi akan bertahan, berperan dan memenangkan persaingan. Salah satu hal penting dalam manajemen strategi adalah pengawasan. Setelah strategi disusun, dilaksanakan maka diperlukan pengawasan agar dapat dicapai apa yang direncanakan organisasi. Untuk melanggengkan keberadaannya, keunggulan kompetitif tersebut juga harus berkelanjutan (sustainable). Kelanggengan yang dicapai secara berkelanjutan akan membawa organisasi pada kinerja yang baik yang berujung pada diperolehnya keuntungan (profit) yang tinggi. Keunggulan yang berkelanjutan tidak cukup dengan memilih posisi strategi dan unik, karena adanya unsur pesaing (Porter,1996). Keunggulan kompetitif yang berkelanjutan merupakan bentuk-bentuk strategi untuk membantu dalam mempertahankan kelangsungan hidup organisasi (Day \& Wensley,1988). Organisasi perlu mengukur dan menilai kinerjanya agak mampu mencapai keunggulan kompetitif. Kinerja organisasi diukur secara komprehensif yang mencakup aspek keuangan dan aspek non keuangan. Sistem penilaian kinerja dengan melihat aspek keuangan dan aspek non keuangan bisa dilakukan dengan model Balanced Score Card. Keunggulan model Balanced Score Card dikarenakan adanya Key Performance Indicator (KPI) sebagai metrik terkecil yang dimunculkan dari terjemahan strategi organisasi. KPI merupakan indikator/ukuran yang dicapai untuk mengukur tingkat pencapaian kinerja terhadap sasaran strategi organisasi yang telah ditentukan. 
INOBIS: Jurnal Inovasi Bisnis dan Manajemen Indonesia

Volume 1, Nomor 1, Desember 2017

Utik Bidayati

\section{Ringkasan Isi Artikel}

Makalah yang disusun ini akan mengulas dan mencermati jurnal yang membahas balance scordcard dari beberapa aspek. Jurnal utama yang diulas adalah " Developing a model for the influence of perceived organizational climate on organizational citizenship behaviour and organizational performance based on balanced score card", (Shahin, Naftchali, Pool ,2014). Jurnal tersebut mengulas pencapaian kinerja organisasi dengan mengembangkan model yang berkaitan dengan iklim organisasi yang dirasakan pada perilaku kewargaan organisasi (Organization citizenship behavior/OCB) dengan menggunakan balance scorcard. Beberapa penelitian telah mengkaitkan balance scorecard dengan berbagai aspek lain. Diantara hasil riset menunjukkan adanya peran balance scorecard dalam pemberdayaan secara psikologi dan komitmen organisasional (Huang, Shi, Zhang, \& Cheung, 2006). Balance score card dalam keadilan (Asgari, Silong, Ahmad, \& Samah, 2008), perilaku kewargaan organisasional (OCB) dan pada akhirnya juga berdampak pada kinerja (misal, Wang et al., 2005; Chahal \& Mehta, 2010).

Pada tulisan Shahin, Naftchali, Pool (2014) ditunjukkan bahwa organization citizenship behavior (OCB) menggambarkan perilaku individu yang ekstra yang tidak secara langsung atau eksplisit dapat dikenali dalam sebuah sistem kerja yang formal. Diawali dengan kinerja individual, kemudian masuk dalam kinerja tim serta kelompok kerja, dan kinerja organisasi secara menyeluruh. Sumberdaya manusia yang berada pada kondisi perilaku OCB, dengan kesadaran diri dan sukarela akan dinilai banyak berpengaruh pada kinerja organisasi.

Penelitian tersebut merupakan studi pertama yang telah dilakukan tentang integrasi dari tiga variabel dibahas iklim organisasi, perilaku warga organisasi / organization citizenship behavior (OCB), dan kinerja berdasarkan pada BSC. Penelitian ini mencoba untuk membahas iklim organisasi yang berdampak pada perilaku kewargaan organisasional dengan menggunakan model yang dikembangkan dari Balance Scoredcard. Jika hubungan diasumsikan disetujui, manajer dapat menumbuhkan latar belakang perilaku warga organisasi, dan akibatnya organisasi saksi peningkatan kinerja organisasi yang merupakan faktor penting bagi mereka kemajuan dan kelangsungan hidup.

\section{a. Teori Dasar OCB, iklim kerja, BSC dan Kinerja}

Konsep organisational citizen behavior atau perilaku kewargaan organisasional pertama kali diperkenalkan oleh Organ et al., 2006 di tahun 1980-an (Hua dan Yu, 2011). Organ percaya bahwa organisasi perilaku kewargaan adalah perilaku individu dan belum didefinisikan secara langsung dalam sistem reward formal dalam organisasi; melakukannya menyebabkan peningkatan efektifitas dan efisiensi kinerja organisasi (Appelbaum et al, 2004;.. Balai et al, 2009). Perilaku ini tidak termasuk di antara deskripsi pekerjaan atau perilaku formal, dan itu bukan merupakan komitmen kerja bagi orang-orang. OCB didefinisikan sebagai jenis perilaku individu dan organisasi yang lebih seperti pilihan pribadi (Hua dan Yu, 2011). Definisi ini menekankan tiga fitur utama dari perilaku warga organisasi. Pertama, perilaku ini harus bersifat sukarela; kedua, keuntungan dari perilaku ini memiliki dampak organisasi; dan ketiga, perilaku warga organisasi adalah entitas multi-faceted (Bolino et al) . Didefinisikan perilaku warga organisasi sebagai kecenderungan dan motivasi karyawan yang berjalan melampaui kebutuhan kerja formal untuk membantu satu sama lain, untuk menyelaraskan kepentingan individu dengan kepentingan organisasi, dan memiliki kepedulian nyata terhadap kegiatan umum dan misi organisasi. Mereka percaya bahwa perilaku warga memiliki dua umum fitur secara umum: pertama, mereka tidak dapat diperkuat 
INOBIS: Jurnal Inovasi Bisnis dan Manajemen Indonesia

Volume 1, Nomor 1, Desember 2017

\section{Utik Bidayati}

secara langsung, dan kedua, mereka upaya khusus dan luar biasa bahwa sebuah organisasi mengharapkan dari karyawan di memesan untuk mencapai keberhasilan (Korkmaz dan Arpaci, 2009). Ahli lainnya menentukan perilaku warga organisasi sebagai semacam perilaku informal di mana orang bertindak di luar apa yang telah diharapkan dari mereka, dan membantu kesejahteraan organisasi dan keselamatan orang-orang yang berada di dalamnya. Perilaku warga organisasi adalah seperangkat positif dan menguntungkan perilaku organisasi yang menghasilkan hubungan multi-dimensi dengan positif konsekuensi organisasi (Jahangir dan Hag, 2004).

Konsep iklim organisasi menjadi populer di bidang psikologi industri dan organisasi (Kaushik, 2007; Foote dan Tang, 2008) sebelum muncul konsep budaya organisasi budaya yang dikembangkan di akhir 1980-an. Thomas (1998) percaya bahwa iklim didefinisikan sebagai persepsi umum dari kualitas fenomena alam di tempat, dengan kata lain itu adalah aspek budaya. Reichard dan Schneider (1990) mendifinisikan iklim sebagai sudut pandang organisasi, dan langkah-langkah formal atau informal dan metode dalam organisasi. iklim organisasi umumnya tentang sikap dan perilaku (Huseyin, 2008), dan termasuk fitur organisasi yang berdampak pada motivasi dan perilaku mereka yang bekerja di lingkungannya (Chen dan Hung, 2007). Organisatoris iklim menunjukkan suasana yang dominan di suatu perusahaan, persepsi karyawan dari organisasi, umpan balik dari kerjasama dan tingkat persahabatan, saling percaya, dan orang saling melindungi. Dengan demikian, iklim organisasi dapat dianggap sebagai persepsi yang sama dari perangkat internal organisasi di berbagai tingkatan dari hirarki organisasi (Asif, 2011), dan dapat dievaluasi oleh persepsi dan deskripsi karyawan tentang fitur internal organisasi (Dickson et al., 2004).

Jaw dan Liu (2003) medifinisikan iklim organisasi dengan dua pendekatan yaitu iklim koperasi dan iklim yang inovatif. Ketika perusahaan menawarkan pada tingkat tinggi iklim inovatif, karyawan cenderung meningkatkan interaksi mereka dengan orang lain untuk melakukan pertukaran dan berbagi pengetahuan untuk menciptakan hal baru, oleh karena itu iklim inovatif mengembangkan interaksi sosial antara anggota organisasi (Hoegl et al., 2003). Adanya iklim koperasi dalam suatu organisasi adalah pencipta alasan untuk meningkatkan kecenderungan aggota organisasi yang bekerja satu sama lain sebagai kelompok untuk mempromosikan satu sama lain (Janz dan Prasarnphanich, 2003).

Mengevaluasi kinerja bisnis adalah salah satu agenda manajemen yang paling penting; karena kunci untuk mengakses perbaikan terus-menerus dalam kemampuan untuk terus mengevaluasi kinerja organisasi. Banyak organisasi telah memahami pentingnya evaluasi terus menerus kinerja, dan mereka menerapkan berbagai pendekatan untuk evaluasi kinerja dalam organisasi (Fernandes et al., 2006). Antara tahun 1850 - 1975, organisasi telah mulai melakukan evaluasi kinerja dengan semata-mata menggunakan kriteria keuangan. Langkah tersebut mendapat karena alasan seperti itu mendorong sudut pandang jangka pendek, kurang berpikir strategis dan tidak memiliki kemampuan untuk menyediakan data tentang kualitas, responsif, dan fleksibilitas, sehingga mendorong sudut pandang optimis, dan gagal untuk memberikan informasi tentang apa yang pelanggan inginkan dan kualitas kinerja pesaing. Untuk mengatasi hal tersebut disusun pengukuran kinerja dengan menggunakan balance scorecard.

Kelengkapan Balance Scorecard (BSC) untuk mengevaluasi kinerja dan meningkatkan penggunaannya untuk topik manajemen strategis menggunakan empat aspek sebagai dasar untuk mengevaluasi kinerja organisasi. BSC mengukur secara komprehensif kerangka bagi manajer untuk memodifikasi strategi perusahaan untuk seperangkat kriteria kinerja (Kaplan dan Norton, 1992). BSC berbeda dengan sistem evaluasi tradisional yang hanya termasuk kriteria keuangan. BSC telah dirancang sedemikian rupa bahwa hal itu meningkatkan 
INOBIS: Jurnal Inovasi Bisnis dan Manajemen Indonesia

Volume 1, Nomor 1, Desember 2017

\section{Utik Bidayati}

keputusan manajer 'keputusan melalui terkemuka perhatian mereka terhadap dimensi yang lebih luas dari operasi perusahaan (Shahin dan Zairi, 2006;. Shahin et al, 2012).

\section{b. Metode Penelitian.}

Pada tulisan yang dilakukan analisis ini, peneliti menentukan populasi statistiknya yaitu para manajer usaha kecil dan menengah di Mazandarna yang berjumlah 600 orang dengan menggunakan sistem random sampling. Data diperoleh dengan kuesioner pada responden yang selanjutnya dianalisis dengan persamaan strukturan modeling (SEM) menggunakan sofware SPSS 18 dan AMOS 18. Kuesioner disusun dengan mengadopsi beberapa instrumen pertanyaan yang pernah dilakukan oleh peneliti lain dalam penelitian sebelumnya. Untuk mengevaluasi perilaku warga organisasi skala digunakan 16 pertanyaan yang berasal dari kuesioner dari Bell dan Menguc (2002). Untuk mengevaluasi iklim organisasi digunakan kuesioner dari GU 1 (2008) sejumlah 38 pertanyaan. Beberapa perubahan dilakukan dalam instrumen ini untuk mengakomodasi situasi dalam organisasi yang berada di Iran sesuai dengan tempat penelitian dilakukan. Sebuah kuesioner dengan 16 pertanyaan berdasarkan pendekatan BSC Kaplan dan Norton (1992) digunakan untuk mengevaluasi kinerja kecil untuk perusahaan menengah. Populasi yang merespon penelitian dengan mengembalikan kuesioner sebanyak 321.

Hipotesis yang dibangun oleh peneliti dengan berdasarkan pada beberapa tulisan adalah, adanya dampak perilaku warga organisasi pada kinerja perusahaan, perilaku warga organisasi memiliki dampak pada kinerja perusahaan dalam kriteria keuangan, kriteria pelanggan maupun dalam kriteria proses internal. Penulis juga membangun dugaan awal bahwa perilaku warga organisasi memiliki dampak pada kinerja perusahaan dalam pertumbuhan dan pembelajaran kriteria.

Iklim organisasi yang dirasakan memiliki dampak pada perilaku warga organisasi, dalam hal kinerja perusahaan pada kriteria keuangan, kriteria pelanggan maupun kriteria proses internal. Iklim organisasi dirasakan memiliki dampak pada kinerja perusahaan dalam pertumbuhan dan pembelajaran kriteria.

\section{c. Proses dan hasil uji}

Proses yang dilakukan Shahin, Naftchali, Pool (2014) dalam penelitiannya diawali dengan menyebar intrumen penelitian yang berupa kuesioner, peneliti melakukan uji instrumen dengan konfirmatori faktor analisis (CFA). Dari semua butir instrumen dapat diketahui kesemuanya valid, sehingga dapat dipakai sebagai intrumen pengumpul data. Selanjutnya uji hipotesis menunjukkan hasil bahwa hanya ada 1 hipotesis yang tidak terdukung, yaitu hipotesis H3c. dimana hasil uji menunjukkan bahwa iklim organisasi yang dirasakan tidak memiliki dampak pada kinerja perusahaan kriteria proses internal.

\section{d. Pembahasan, Diskusi dan Implikasi}

Hasil pengujian hipotesis yang dilakukan penulis menujukkan hampir semua dapat terdukung. Sehingga menunjukkan bahwa perilaku kewargaan organisasi yang merupakan perilaku anggota organisasi yang melebihi standar yang diharapkan organisasi berpengaruh terhadap kinerja organisasi dengan proses evaluasi melalui balance scorecard yaitu kinerja keuangan, kepuasan pelanggan, proses internal dan pembelajaran serta pengembangan. Secara umum hasil ini sesuai dengan penelitian sebelumnya yang berkaitan dengan kinerja 
INOBIS: Jurnal Inovasi Bisnis dan Manajemen Indonesia

Volume 1, Nomor 1, Desember 2017

\section{Utik Bidayati}

organisasi. Namun yang membedakan pada penelitian yang dilakukan oleh Shanin et al. ini dengan penelitian sebelumnya adalah, peneliti menggunakan balance scorecard dalam mengukur kinerja perusahaan. Sehingga hasil penelitian lebih mendukung penelitianpenelitian sebelumnya seperti yang dilakukan Schneider et al. (2009), yang menunjukkan dampak positif dari iklim organisasi terhadap kinerja keuangan, kepuasan pelanggan, pasar kinerja, dan bisnis. Juga penelitan yang dilakukan Jing et al., (2011) dimana hasilnya menunjukkan bahwa iklim organisasi memiliki dampak positif pada kinerja organisasi.

Keterbatasan yang ada dalam penelitian yang dilakukan Shahin, Naftchali, Pool (2014) ini dapat menjadi celah penelitian lanjutan. Celah yang dimaksud adalah pada penelitian kinerja organisasi kebanyakan dilakukan pada perusahaan menengah dan kecil, sehingga ketersediaan data yang dapat diolah dengan menggunakan balance scorecard terbatas. Penelitian dengan sampel perusahaan besar dapat dilakukan oleh peneliti lajutan, dimana diharapkan pada perusahaan besar data berkaitan dengan kinerja organisasi lebih banyak dan lengkap.

\section{Review dan Pembahasan Literatur}

Jurnal utama yang dibahas ini secara umum menggambarkan bahwa OCB dan iklim organisasi mempengaruhi kinerja organisasi. Hal yang membedakan penelitian ini dengan penelitiansebelumnya adalah dalam pengukuran kinerja organisasi, peneliti menggunakan balance scorecard sebagai alat ukur kinerja organisasi. Peneliti juga menggunakan obyek penelitian perusahaan menegah dan kecil di Iran yang dianggap hal ini membatasi perolehan data penelitian.

Pada penelitian lain yang membahas balance scorecard sebagai alat ukur kinerja seperti yang dilakukan Punniyamoorthy dan Murali (2008), menunjukkan pengukuran kinerja menggunakan balance scorecard mampu membantu organisasi melihat secara obyektif dengan parameter yang lebih rinci. Meena (2009) memberikan gambaran bahwa penggunaan balance scorecard sangat menguntungkan organisasi dalam merancang strategi untuk memenuhi harapan pelanggan baik eksternal maupun internal. Sehingga pengukuran kinerja dengan menggunakan bamace scorecard dapat membuat organisasi lebih tepat dalam menilai kinerjanya.

\section{Kesimpulan}

Balance scorecard merupakan salah satu alat untuk mengukur kinerja organisasi. Penggunaan dasar pengukuran dari sisi finansial dan non finasial dapat memperkaya informasi bagi perusahaan dalam merumuskan strategi. Balance scorecard mengukur kinerja organisasi dengan melihat faktor pelanggan, kinerja finansial organisasi, perkembangan dan pembelajaran serta internal proses. Keunggulan balance scorecard yang lain adalah adanya Key performance indikator (KPI). KPI yang ditetapkan dalam balance scorecard membantu perusahaan menentukan target pencapaian yang lebih jelas. Selain itu adanya KPI dapat memberikan informasi yang lebih tepat tentang hasil pencapaian kinerja perusahaan. Penggunaan pengukuran kinerja dengan BSC saat ini semakin berkembang, namun penggunaannya masih terbatas pada bidang kerja organisasi tertentu terutama dalam organisasi bisnis. Sehingga masih terbuka bagi penelitian yang lebih lanjut untuk memperluas pemanfaatan alat pengukuran pencapain kinerja organisasi ini. 
INOBIS: Jurnal Inovasi Bisnis dan Manajemen Indonesia

Volume 1, Nomor 1, Desember 2017

Utik Bidayati

\section{Daftar pustaka}

Chavan, Meena, (2009),"The balanced scorecard: a new challenge", Journal of Management Development, Vol. 28 Iss 5 pp. 393 - 406

David, r Fred, David, R Forest,(2015), Strategic Management : A Competitive Advantage Approach, Concepts \& Cases, 15th Edition,Pearson Education, UK

Kaplan, R.S. and Norton, D.P. (n.d.), The Strategy Focused Organizations, Harvard Business School Press, Boston, MA, pp. 1-30, 369-80.

M. Punniyamoorthy R. Murali, (2008),"Balanced score for the balanced scorecard: a benchmarking tool", Benchmarking: An International Journal, Vol. 15 Iss 4 pp. 420 - 443

Shahin, Arash; Naftchali, Javad Shabani; Pool, Javad Khazaei , (2014),"Developing a model for the influence of perceived organizational climate on organizational citizenship behaviour and organizational performance based on balanced score card", International Journal of Productivity and Performance Management, Vol. 63,Iss 3 pp. 290 - 307

Porter, M.E. (1985), Competitive Advantage: Creating and Sustaining Superior Performance, Free Press, New York, NY. 